\title{
ВЧИНЕННЯ КРИМІНАЛЬНОГО ПРАВОПОРУШЕННЯ УПОВНОВАЖЕНОЮ ОСОБОЮ ЮРИДИЧНОЇ ОСОБИ ЯК ОБСТАВИНА, ЯКА ПІДЛЯГАЕ ДОКАЗУВАННЮ
}

\section{ПАНЬКО Мар'яна Свгенівна - аспірант кафедри кримінального права та процесу Львівського торговельно-економічного університету}

DOI 10.32782/EP.2021.21

\begin{abstract}
Розглянуто процесуальні особливості притягнення до відповідальності юридичной особи у кримінальному провадженні. Акцентовано увагу на тому, що обставини, які $\epsilon$ підставою для застосування до юридичних осіб заходів кримінально-правового характеpy, підлягають доказуванню у кримінальному провадженні. Тому в таких кримінальних провадженнях доказуванню підлягають як винуватість фбізичної особи у вчиненні інкримінованого кримінального правопорушення, так і наявність підстав для застосування заходів кримінально-правового характеру до юридичної особи.

Розкрито зміст підстав для застосування заходів кримінально-правового характеру до юридичної особи. Проаналізовано судову практику. Зроблено висновок, шо кримінальне правопорушення може бути визнано вчиненим від імені юридичної особи, якщо уповноважена бозична особа діяла при цьому саме як представник юридичної особи, тобто уособлювала таку юридичну особу та реалізовувала правосуб'єктність останньої. Окреслено методику і тактику збору доказів для встановлення наявності підстав для застосування заходів кримінально-правового характеру щодо юридичної особи. Розглянуто особливості надання доступу до матеріалів досудового розслідування.

Ключові слова: юридична особа, щодо якої здійснюеться кримінальне провадження, заходи кримінально-правового характеру, уповноважена особа.
\end{abstract}

\section{Постановка проблеми}

На підставі Закону України від 23 травня 2013 року № 314-VII «Про внесення змін до деяких законодавчих актів України щодо виконання Плану дій щодо лібералізації Європейським Союзом візового режиму для України стосовно відповідальності юридичних осіб», до КПК України (п.7 ч.1 ст. 91) та Загальної частини КК України (статті 96-1 - 96-10 Розділу XIV1) були внесені зміни, в частині введення інституту заходів кримінально-правового характеру щодо юридичних осіб. У пояснювальній записці до проєкту цього Закону зазначено, що з метою протидії злочинній діяльності в інтересах юридичних осіб на міжнародному рівні низкою міжнародних договорів, серед яких, зокрема, Кримінальна конвенція про боротьбу з корупцією від 27 січня 1999 р., Конвенція Ради Європи про запобігання тероризму від 16 травня 2006 р., Міжнародна конвенція про боротьбу з фінансуванням тероризму від 9 грудня 1999 р., учасницею яких є також і Україна, передбачено обов'язок державучасниць щодо запровадження відповідальності юридичних осіб за передбачені цими міжнародно-правовими актами злочини. Окрім того, вказується, що вищезазначений Закон спрямований на забезпечення виконання рекомендацій Групи держав проти корупції (GRECO), Спеціального Комітету експертів Ради Свропи 3 питань оцінки заходів боротьби з відмиванням коштів (MONEYVAL), а також на 


\section{Кримінальне право, кримінальний процес та криміналістика}

вирішення питань про реалізацію деяких міжнародних договорів України в частині встановлення відповідальності юридичних осіб». Відповідні нововведення опинилися під пильним науковим прицілом та отримали як підтримку, так і гостру критику, оскільки «новелізація чинного законодавства в ракурсі встановлення заходів кримінально-правового характеру щодо юридичних осіб спричинила більше запитань, ніж відповідей» [1, с. 96].

\section{Стан дослідження}

Деякі кримінально-процесуальні дослідження висвітлюють тільки фрагментарно окремі питання, які пов'язані 3 доказуванням обставин, які є підставою для застосування щодо юридичних осіб заходів кримінально-правового характеру. Так, одні автори розглядали це поняття через призму предмета доказування у кримінальному провадженні [2; 3], процесуальних аспектів застосування цього інституту [4; 5], інші - вивчали міжнародне співробітництво у кримінальних провадженнях щодо юридичних осіб [6].

Втім на сьогодні база знань не піддавалась аналізу на предмет ступеня наукового забезпечення процесу доказування обставин, які є підставою для застосування щодо юридичних осіб заходів кримінально-правового характеру. Здебільшого науковці розглядали лише окремі аспекти цього питання в рамках наукових статей, у науковопрактичних коментарях до КПК України чи доповідях на конференціях.

Таким чином, основною метою цієї статті є з'ясування особливостей вчинення злочину уповноваженою особою як обставини, яка підлягає доказуванню для застосування.

\section{Виклад основних положень}

Вчинення кримінального правопорушення уповноваженою фізичною особою безпосередньо пов'язано з питанням визначення того, хто стоїть за діями юридичної особи, чиї дії, у тому числі злочинні, визнаються діями підприємства, установи чи організації [7, с.244]. У п.1 примітки до ст.96-3 КК України зазначено, що уповноважени- ми особами юридичної особи є дві категорії осіб, а саме:

1) службові особи юридичної особи;

2) інші особи, які відповідно до закону, установчих документів юридичної особи чи договору мають право діяти від іiї імені.

Власне визначення поняття службових осіб передбачене у ч.3 ст.18 КК України. Зокрема, ними вважаються особи, які постійно, тимчасово чи за спеціальним повноваженням здійснюють функції представників влади чи місцевого самоврядування, а також постійно чи тимчасово обіймають в органах державної влади, органах місцевого самоврядування, на підприємствах, в установах чи організаціях посади, пов'язані 3 виконанням організаційно-розпорядчих чи адміністративно-господарських функцій, або виконують такі функції за спеціальним повноваженням.

Службовими особами відповідно до ч.4 ст.18 КК України також визнаються посадові особи іноземних держав, іноземні третейські судді, особи, уповноважені вирішувати цивільні, комерційні або трудові спори в іноземних державах у порядку, альтернативному судовому, посадові особи міжнародних організацій, а також члени міжнародних парламентських асамблей, учасником яких є Україна, та судді і посадові особи міжнародних судів.

Відповідно до положень ЦК України представництво виникає на підставі договору, закону, акта органу юридичної особи, а також 3 інших підстав, встановлених актами цивільного законодавства (ч.3 ст.237). Звідси випливає, що у примітці до ст.96-3 КК України законодавець при визначенні поняття «уповноважена особа» не вказав у переліку осіб, які діють від імені юридичної особи на підставі акта органу юридичної особи.

Суть представництва на підставі договору полягає у тому, що юридична особа укладає угоду 3 фізичною особою 3 метою встановлення та регулювання певних правовідносин від імені та в інтересах юридичної особи. Як правило, передача повноважень відбувається на підставі договору доручення, за яким одна сторона (повірений) зобов'язується вчинити від імені та за 
рахунок другої сторони (довірителя) певні юридичні дії. Правочин, вчинений повіреним, створюе, змінюе, припиняе цивільні права та обов'язки довірителя. Договором доручення може бути встановлено виключне право повіреного на вчинення від імені та за рахунок довірителя всіх або частини юридичних дій, передбачених договором. У договорі можуть бути встановлені строк дії такого доручення та (або) територія, у межах якої є чинним виключне право повіреного (ст.1000 ЦК України). Що стосується представництва інтересів юридичної особи на підставі закону, то власне воно виникає в силу імперативних приписів чинного законодавства. Так, у ч.1 ст.122 ЦК України вказується, що кожний учасник повного товариства має право діяти від імені товариства, якщо засновницьким договором не визначено, що всі учасники ведуть справи спільно або що ведення справ доручено окремим учасникам.

Наступний вид представництва юридичних осіб від їх імені здійснюється на підставі установчих документів, до яких слід відносити: рішення про утворення або засновницький договір суб'єкта господарювання, а у випадках, передбачених законом, його статут (положення) (ч.1 ст.57 ГК України); статут або засновницький договір між учасниками (ч.2 ст.87 ЦК України); установчий акт, статут, програма політичної партії, модельний статут, засновницький договір, меморандум, положення (п.17 ч.1 ст.1 ЗУ «Про державну реєстрацію юридичних осіб, фізичних осіб-підприємців та громадських формувань» від 15 березня 2003 р.). Врешті-решт, представництвом на підставі акту юридичної особи згідно з ч.2 ст.244 ЦК України вважаються правовідносини, у яких представник діє від імені та в інтересах юридичної особи, які він представляє, у межах, визначених змістом розпорядчого акта.

Виходячи 3 цих положень, статус особи як уповноваженої повинен бути визначений (закріплений) у відповідних документах, які у відповідності до ст.98 КПК України, є матеріальними об'єктами, що містять відомості, які можуть бути використані як доказ факту чи обставин, що встановлюють- ся. Такі документи можуть бути як речові докази у кримінальному провадженні.

Аналіз судової практики, яка міститься в Сдиному державному реєстрі судових рішень України засвідчує, що органами досудового розслідування використовуються два способи здобуття (вилучення) документів: 1) тимчасовий доступ до речей і документів на підставі ухвали слідчого судді; 2) обшук з метою відшукання зазначених матеріальних об'єктів. Вибір того чи іншого способу здобуття відповідних документів визначається на розсуд слідчого та прокурора, виходячи $з$ обставин кримінального провадження. У цьому випадку слідчому важливо мати інформацію про наявність конкретних документів та їх місце знаходження, а також наявність ризиків щодо приховування, зміни або знищення їх володільцем. Значно простішим є випадки, коли відомий повний перелік документів, їх місцезнаходження та відсутні відповідні ризики. У такому разі на підставі ухвали слідчого судді здійснюється тимчасовий доступ до оригіналів з можливістю їх вилучення. Як приклад слід навести ухвалу слідчого судді Солом'янського районного суду міста Києва від 16 серпня 2018 р. Так, слідчий, за погодження 3 прокурором, звернувся до слідчого судді з клопотанням про тимчасовий доступ до документів ТОВ «Капітал-Буд Груп», які перебувають у володінні Чернівецької міської ради, з наданням дозволу на здійснення виїмки оригіналів документів, вказуючи, що зазначені документи мають значення в кримінальному провадженні. Органом досудового розслідування встановлено, що ТОВ «Капітал-Буд Груп» є одним з суб'єктів господарювання з ознаками фіктивності, яке причетне до привласнення державного майна, що перебуває у користуванні ДП «РПЦ», а також легалізації (відмивання) доходів, одержаних протиправним шляхом.

Керуючись ст.159, 160, 162-164 КПК України, слідчий суддя постановив клопотання задовольнити частково, надавши слідчому тимчасовий доступ до документів ТОВ «Капітал-Буд Груп» 3 можливістю вилучення їх копій, а саме: статуту, змін до статуту, змін до установчих документів; на- 


\section{Кримінальне право, кримінальний процес та криміналістика}

казів про призначення службових осіб товариства; реєстраційних карток про проведення державної реєстрації; довіреностей на представництво інтересів товариства; документів щодо внесення грошових коштів та матеріальних цінностей, їх виведення зі статутного капіталу підприємства; інших документів реєстраційної справи [8].

Зрозумілим є той факт, що нерідко уповноважена особа або за її вказівкою інші особи можуть вживати заходів щодо перешкоджання здобуття стороною обвинувачення таких документів, оскільки вони будуть доказувати взаємозв'язок юридичної особи 3 відповідною особою. Так, у разі наявності ризиків щодо приховування, зміни або знищення документів доцільно буде провести обшук з метою їх відшукання. Проведення обшуку здійснюється також у випадку, коли місцезнаходження документів та їх перелік є невідомим. Така практика є доволі поширеною, оскільки непоодинокими є випадки, коли місце реєстрації та фактичне знаходження юридичної особи є різними. Окрім того, уповноважені особи юридичної особи можуть зберігати відповідні документи поза місцем їі знаходження. У такому випадку органу досудового розслідування необхідно вжити заходів щодо встановлення їх місця знаходження, відпрацювання інших осіб, причетних до вчинення кримінального правопорушення (родичів, друзів, працівників).

Як правило, такі заходи вживаються шляхом залучення осіб до конфіденційного співробітництва та проведення негласних слідчих (розшукових) дій щодо осіб - фігурантів кримінального провадження. Таким чином, можна встановити їх злочинні зв'язки, місця тривалого перебування та проживання, способи приховування злочинної діяльності, зокрема і документів. Так, шляхом проведення зняття інформації 3 транспортних телекомунікаційних мереж можна встановити коло осіб, з якими контактуе фігурант, зміст його розмов, у тому числі, надання вказівок щодо приховування, перевезення та забезпечення зберігання відповідних документів. Зрозуміло, що особи-фігуранти кримінального провадження здійснюють конспірування своєї злочинної діяльності, а тому важливим є проведення одночасного комплексу слідчих (розшукових) та негласних слідчих (розшукових) дій. Наприклад, у випадку, коли уповноважена особа в телефонному режимі надає іншій особі вказівки щодо приховування та подальшого переміщення в умовне місце відповідних документів, то важливим буде проведення щодо останньої особи візуального спостереження та установлення місцезнаходження радіоелектронного засобу, оскільки така особа може привести до безпосереднього місця зберігання, з якого їх у подальшому можна буде вилучити.

У випадку встановлення місцезнаходження відповідних документів та їх вилучення, тактично правильно буде провести слідчі (процесуальні) дії щодо дослідження їх змісту, підстав видачі, а також ідентифікації осіб, які їх підписали. Метою дослідження змісту того чи іншого документа E власне встановлення факту виконання відповідною особою організаційно-розпорядчих чи адміністративно-господарських функцій. Таке дослідження проводиться в ході здійснення огляду документів. Втім у разі заперечення уповноваженою особою факту покладення на неї відповідних функцій, органу досудового розслідування необхідно призначити проведення експертиз, a саме: почеркознавчої (щодо дослідження підпису), молекулярно-генетичної (щодо виявлення на документі слідів біологічного походження (крові, букального епітелію тощо), встановлення генетичних ознак та їх приналежність відповідній особі), технічної експертизи документів (щодо визначення способу виготовлення відповідного документу, ідентифікації відтисків печаток та визначення послідовності відповідних дій). У такому випадку важливим для органу досудового розслідування є розуміти послідовність вчинення відповідних дій, оскільки первинне проведення оглядів та експертних досліджень, може ускладнити та унеможливити проведення в подальшому молекулярно-генетичної експертизи, або знищити сліди біологічного походження, які там знаходились. Втім, такий підхід повинен вживатись слідчим під час безпосереднього вилучення таких документів. 
Окрім того, діяльність органу досудового розслідування щодо дослідження відповідних документів повинна спрямовуватись щодо визначення порядку видачі, реєстрації, підписання та нотаріального посвідчення того чи іншого документа. У такому випадку необхідно здійснити тимчасові доступи до нотаріальних книг та журналів реєстрації (обліку) нотаріальних дій.

Окремо необхідно розглянути специфіку доказування у випадку, коли слідством не здобуто документів, які безпосередньо будуть доказувати взаємозв'язок юридичної особи з відповідною особою. Такі ситуації можуть мати місце у випадку їх знищення чи приховування. У такому разі органом досудового розслідування більш широко має досліджуватись сама діяльність юридичної особи та безпосередня діяльність кожного 3 ii службових осіб. Метою такого дослідження має бути встановлення осіб, які в період вчинення кримінального правопорушення, що є предметом розслідування, шляхом укладення інших, не пов'язаних з розслідування правочинів від імені юридичної особи, виступали як її уповноважені особи. Відповідне доказування полягає в отриманні інформації з Єдиного державного реєстру юридичних осіб, фізичних осіб-підприємців та громадських формувань, Сдиних та державних реєстрів у сфері нотаріату про юридичну особу (хто ії уповноважена особа, період виконання нею функцій, хто є підписантом документів, наявність бенефіціарних власників, розмір статутного капіталу та статут), а також інформації про правочини (договори, довіреності), які від ії імені посвідчувались у визначений період. Також можна отримати інформацію з Единого реєстру податкових накладних та інших державних реєстрів, у яких засвідчується інформація про діяльність юридичної особи та її уповноважених осіб. Наявність такої інформації надасть змогу органу досудового розслідування скерувати в подальшому свою діяльність на відшукання та вилучення оригінальних примірників документів, які б за своїм змістом підтверджували, що в період вчинення кримінального правопорушення, що $є$ предметом досудового розслідування, та чи інша особа $є$ уповно- важеною особою юридичної особи. Як правило, така діяльність вчиняється шляхом здійснення тимчасових доступів, обшуків, а також допитів осіб, яким відомі обставини про діяльність відповідної юридичної особи та їі уповноважених осіб. Також у ході доказування відповідної обставини важливими $є$ результати негласних слідчих (розшукових) дій, оскільки під час їх проведення можна зафіксувати, що особа фактично виконувала організаційно-розпорядчі функції, тобто була уповноваженою особою юридичної особи.

\section{Висновки}

Таким чином, вивчення поняття та підстав застосування щодо юридичних осіб заходів кримінально-правового характеру виступають основою для формування працівниками правоохоронних органів уявлень про обставини, які повинні бути встановлені під час проведення системи слідчих (розшукових) та негласних слідчих (розшукових) дій та інших процесуальних дій, що сприяє вибору оптимальних методів боротьби зі злочинністю.

\section{Література}

1. Шинкарьов Ю. В. Правовий аналіз окремих новел законодавства про кримінальну відповідальність / Ю. В. Шинкарьов // Збірник наукових праць Харківського національного педагогічного ун-ту іменіГ. С. Сковороди. - Серія «Право». - Вип. 21, 2014. - С. 96-100.

2. Жовтан П.В. Предмет доказування у кримінальному провадженні про прийняття пропозиції, обіцянки або одержання неправомірної вигоди службовою особою / П.В. Жовтан // Боротьба з організованою злочинністю та корупцією: теорія і практика. - №2 (33) - 2014 р. - С.50-53

3. Форостяний А.В. Щодо розширення предмета доказування у кримінальному провадженні / А.В. Форостяний // Юридична наука. - №3 - 2015 р. - С. 152-158

4. Михайленко В. Процесуальні аспекти інституту заходів кримінально-правового характеру щодо юридичної особи в сучасних умовах правового регулювання. Застосування заходів кримінально-правового 


\section{Кримінальне право, кримінальний процес та криміналістика}

характеру щодо юридичних осіб: матеріали міжнародного круглого столу (30 липня 2019 року). Київ:Національна академія прокуратури України, 2019. - С.72-77

5. Скок О., Шевченко Т. Деякі питання щодо застосування заходів кримінальноправового характеру до юридичних осіб; Застосування заходів кримінально-правового характеру щодо юридичних осіб: матеріали міжнародного круглого столу (30 липня 2019 року). Київ:Національна академія прокуратури України, 2019. - С.78-80

6. Ахтирська Н. Міжнародне співробітництво у кримінальних провадженнях щодо юридичних осіб (законодавчий та організаційні аспекти). Застосування заходів кримінально-правового характеру щодо юридичних осіб: матеріали міжнародного круглого столу (30 липня 2019 року). Київ:Національна академія прокуратури України, 2019. - С.21-25

7. Провоторов О. П. Правові підстави застосування заходів кримінально-правового характеру щодо юридичних осіб за законодавством України. Наука і правоохорона. 2018. № 1. C.- 243-250.

8. Ухвала слідчого судді Солом'янського районного суду міста Києва від 16 серпня 2018 р. Справа № 760/20810/18. URL: http:// reyestr.court.gov.ua/Review/76180194\#

\section{SUMMARY}

In the article are considered procedures features of responsibility of legal entitie in criminal proceeding. The author pays attention on that circumstances that are founding for application to the legal entities of measures of criminal law character and are subjects to proof in criminal proceedings. Therefore, in such criminal proceedings, evidence of the guilt of an individual in committing an incriminated crime, as well as the existence of grounds for the application of criminal-law measures to a legal entity.

The article discloses the content of the grounds for applying the measures of criminal law to a legal entity. Analyzed yudicial practice. It is concluded that the crime can be recognized as committed on behalf of a legal entity if the authorized individual acted as a representative of the legal entity, that is, personified such a legal entity and realized the legal personality of the latter, and did not act privately, acting on its own behalf. The methodology and tactics for collecting evidence to establish the grounds for applying measures of criminal law to a legal entity are defined. Features of providing access to materials of pre-trial investigation are considered.

Key words: legal entity, which is subject to criminal proceedings, measures criminal-law, authorized person. 